\title{
Correction to: Foliar spray of salicylic acid induces physiological and biochemical changes in purslane (Portulaca oleracea L.) under drought stress
}

\author{
Farnaz Saheri $^{1} \cdot$ Giti Barzin $^{1} \cdot$ Leila Pishkar $^{1} \cdot$ Masoud Mashhadi Akbar Boojar $^{2} \cdot$ Laleh Babaeekhou $^{1}$ \\ Published online: 6 November 2020 \\ (C) Plant Science and Biodiversity Centre, Slovak Academy of Sciences 2020
}

\section{Correction to: Biologia}

http://orcid.org/10.2478/s11756-020-00571-2

The original article was published with an error in affiliation 1 . The affiliation has been updated to show the correct department. The original article has been corrected.

Publisher's note Springer Nature remains neutral with regard to jurisdictional claims in published maps and institutional affiliations.

The online version of the original article can be found at https://oi.org/ $10.2478 / \mathrm{s} 11756-020-00571-2$

Giti Barzin

Gitibarzin@iiau.ac.ir

1 Department of Biology, Islamshahr Branch, Islamic Azad University, Islamshahr, Iran

2 Department of Biology Science, Kharazmi University, Tehran, Iran 